\title{
Evaluation of Local Spices as Biopesticides for the Control of Ootheca mutabilis, Shalbera and Clavigralla tomentosicollis (Stal.) on Cultivated Cowpea (Vigna unguiculata L.) in Nigeria
}

\author{
Ime O. Udo ${ }^{1} \&$ Edna A. Akpan ${ }^{2}$ \\ ${ }^{1}$ Department of Crop Science, University of Uyo, Uyo, Nigeria \\ ${ }^{2}$ Department of Crop Science, Akwa Ibom State University, Obio Akpa Campus, Akwa Ibom State, Nigeria \\ Correspondence: Ime O. Udo, Department of Crop Science, University of Uyo, Uyo, Nigeria. Tel: \\ 234-8023-292-513. E-mail: imeudo@yahoo.com
}

Received: March 26, 2012 Accepted: April 16, 2012 Online Published: August 24, 2012

doi:10.5539/jas.v4n10p7 URL: http://dx.doi.org/10.5539/jas.v4n10p7

\begin{abstract}
Two experiments were conducted at the University of Uyo Teaching and Research Farm in 2003 and 2004 to evaluate the impact of aqueous extracts of five local spices as biopesticides for the control of $O$. mutabilis and $C$. tomentosicollis on cultivated cowpea (Vigna unguiculata L.). The spices evaluated were Capsicum annum L., Xylopia aethiopica (Dunal), Piper guineense Schum and Thonn, Allium sativum L. and Zingiber officinale Roscoe. The extracts were applied at 3,4 and 5\% concentrations, respectively to study toxicity, repellency, pod and leaf damage as well as grain yield. The experiment was designed as a Randomized Complete Block Design and replicated three times. Results obtained showed that the biopesticides significantly $(\mathrm{P}<0.05)$ reduced insect population, offered greater protection and promoted better grain yield compared to the control. However, amongst the spices, $P$. guineense consistently induced greater protection by bringing down the population of insects and promoting grain yield. The promising use of spices as biopesticides is discussed since they are available local resources for poor farmers and are environmentally friendly options for pest control.
\end{abstract}

Keywords: spices, biopesticides, cultivated cowpea, aqueous extract, yield

\section{Introduction}

Cowpea [Vigna unguiculata (L.) Walp] belongs to the family fabaceae and has immense economic benefits. The crop is a legume and ranks as the third most important food legume in the tropics after peanut and pigeon pea (FAO, 1986). Cowpea is used as green manure and cover crop to improve soil fertility through nitrogen fixation (Onwueme \& Sinha, 1991). Cowpea is a veritable source of plant protein and could be consumed as green vegetables when immature. As a pulse it is boiled and eaten in combination with other foods like plantain, yam, rice and maize. This combination is a very popular menu in local diets in the tropics. The matured and dried cowpea seeds are also ground into flour and used in making local bean cake called "akara". These are relish for children and adults who could eat them as snacks or use them for breakfast. Cowpea provides farmers with income, planting materials and generates foreign exchange while its cultivation creates employment for both skilled and unskilled workers.

In Nigeria, the crop is grown throughout the country with the highest cultivation recorded in northern Nigeria. With its wider acceptance and cultivation, Nigeria is rated the world's largest producer (FAO, 1986). The crop is rarely grown in pure stands but oftentimes it is intercropped with cassava, sorghum, millet and maize (Akobundu, 1982).

In spite of the numerous utilization of cowpea, production often falls below optimum principally because of insect pests' infestation. The attack by Ootheca mutabilis and Clavigralla tomentosicollis leads to severe impairment of growth, poor grain filling and yield, and subsequently economic losses. The adults of these insects feed on the leaves and flowers of cowpea plant and heavy infestation results in death of plants. The insects are also responsible for the transmission of plant virus like cowpea yellow mosaic virus. In Latin America, Asia and most African countries, losses of about 30\% have been recorded (Jackai et al., 1992). It is therefore necessary to control and protect cultivated cowpea from attack and destruction by these insects. To achieve this, farmers have relied heavily on insecticides which have posed serious adverse effects on the crop, environment and man (Udo 
et al., 2004). Apart from the above consequences, the prohibitive cost, unavailability and irregular supply as well as foreign exchange restrictions have made agrochemicals unaffordable to the resource poor farmers (Obeng-Ofori et al., 1997).

Alternative to chemical treatment has been the use of various plants and plant products in overcoming insect pest infestation of cultivated and stored cowpea. Meaningful results have been obtained using botanicals for pest control. Dike et al. (1996) reported that neem seeds and leaves at 5\% and $10 \%$ concentration respectively controlled insect pests of cultivated cowpea. Similarly, Jackai (1993) reported the use of neem extracts as an effective control agent of insect pests of cowpea. Emosairue and Ubana (1998) showed the effectiveness of neem seed kernel extract at 5\% and 10\% against pod and seed damage by Maruca testulalis. This work therefore evaluates the potential use of aqueous extracts of five local spices in protecting cultivated cowpea and probable influence on grain yield.

\section{Materials and Methods}

The study was conducted at the University of Uyo Teaching and Research Farm during the 2003 and2004 farming seasons. The experimental site lies between latitudes $4^{\circ} 31^{\prime}$ and $5^{\circ} 30^{\prime} \mathrm{N}$ and longitudes $7^{\circ} 28^{\prime}$ and $8^{\circ} 28^{\prime} \mathrm{E}$.

The experimental design used was a randomized complete block design (RCBD) replicated three times. The field was divided into three blocks each measuring $308 \mathrm{~m}^{2}$ (0.0308ha). Each block was divided into 24 subplots each measuring $3.75 \mathrm{~m}^{2}(0.000375 \mathrm{ha})$ thus giving a total of $72 \mathrm{sub}$ plots. A path of $3 \mathrm{~m}$ separated the blocks from each other while a path of $1 \mathrm{~m}$ within rates and a path of $2 \mathrm{~m}$ between rates separated the sub plots from each other.

A local cowpea variety called Ife Brown was used for the experiment and 3 seeds were planted per hole and later thinned to 2 plants per stand. The planting distance used was $30 \mathrm{~cm} \mathrm{X} 60 \mathrm{~cm}$ (Onwueme \& Sinha, 1991) on a plot size of $0.0308 \mathrm{ha}$. Basal NPK (15:15:15) fertilizer was applied at the rate of $150 \mathrm{~kg} / \mathrm{ha}$ two weeks after planting. A total of three weeding were done before crop maturity.

All the five spices, Capsicum annum L., Xylopia aethiopica (Dunal), Piper guineense Schum and Thonn, Allium sativum L. and Zingiber officinale Roscoe were procured from Uyo main market in Nigeria. Seeds of all the spices were air dried in the Agronomy Laboratory, University of Uyo, Nigeria before grinding. A hand mill was used in grinding the seeds of each spice into powder. Three concentration levels of $3 \%, 4 \%$ and $5 \%$ (wt $/ \mathrm{vol}$.) were prepared by mixing $30 \mathrm{~g}, 40 \mathrm{~g}$ and $50 \mathrm{~g}$ of the ground spices in one litre of distilled water and left to stand for 8 hours (Udo, 2005). The solution was filtered using white muslin cloth while the extracts were applied to the cowpea plants in the evenings from 16 - 18 GMT using a 60cl capacity hand held sprayer. The control plot had no extract applied.

The following data were collected from the study including weight of 100 seeds by selecting 100 seeds at random from each treatment and the weight recorded in grams. Grain yield was obtained after harvesting by weighing grains from each treatment and the weights converted to tons per hectare. Mean number of pods per treatment was obtained by taking the total number of pods divided by the number of plants harvested while mean population of insects was recorded at 4,8 and 10 weeks after planting by simply counting the pest present in each treatment. All data generated were subjected to analysis of variance (ANOVA) manually and means separated using LSD and DMRT as described by Wahua (1999).

\section{Results and Discussion}

The mean population of insects as recorded on treated and control plots is shown in Table 1. A significant $(\mathrm{P}<0.05)$ difference was observed amongst the treatments with $P$. guineense treated plots consistently recording the least number of insects 4 weeks after planting. A similar trend was observed 12 weeks after planting with treated plots recording significantly lower number of insects than the control plots. Plots treated with $Z$. officinale and $X$. aethiopica had the lowest mean population of insects 12 weeks after planting. The ability of the spices to protect cultivated cowpea by reducing the damage arising from decrease insect population suggests the presence of insecticidal properties in the spices (Boeke et al., 2004; Udo, 2009). The spices could have acted as deterrents thus preventing the insect pests from settling, feeding and ovipositing on cowpea. Furthermore, the spices may have had toxic effect on adult and immature stages of the insect pests, thus leading to the decreased mean number of insects observed on treated plots (Obeng-Ofori, 1995; Epidi \& Udo, 2009).

The mean number of pods recorded per treatment and for the two seasons is shown in Table 2. There was a significant $(\mathrm{P}<0.05)$ increase in the number of pods in treated plots over the control plots. The result obtained further showed that plots treated with $P$. guineense gave an increasing mean number of pods as the concentration level of the spices was increased from $3 \%$ to $5 \%$. The same trend was observed in plots treated with $X$. aethiopica although there was no significant difference between $P$. guineense and $X$. aethiopica in influencing 
the number of pods. C. annum, A. sativum and Z. officinale showed weaker activity in influencing the mean number of pods and showed no significance at the $3 \%$ level of concentration. However, a significant $(\mathrm{P}<0.05)$ increase in the mean number of pods was observed as the level of concentration was increased from $3 \%$ to $5 \%$ with $C$. anum and $Z$. officinale recording better performance over $A$. sativum. The significant increase in mean number of pods in treated plots demonstrates the ability of the various spices to protect cultivated cowpea from damage by insects. It has been reported (Emosairue \& Uguru, 2001; Denloye \& Makanjuola, 2001) that spices contain chemical principles capable of deterring insect pests from treated plants thus, preventing insects from staying longer on the crop and therefore minimizing the degree of damage. Therefore, the presence of repellent properties in spices has contributed to increased crop production and giving the fact that they are eco-friendly makes them a choice material for replacing synthetic pesticides (Epidi \& Udo, 2009). Apart from the deterrent and repellent properties in the spices, there could be possible mortality arising from insect contact with the spices and this would further reduce the number of insects attacking cultivated cowpea (Udo, 2009).

Table 1. Mean number of pods recorded per treatment for the two seasons

\begin{tabular}{lcccccc}
\hline & \multicolumn{6}{c}{ Treatment levels } \\
\cline { 2 - 7 } Treatment & \multicolumn{2}{c}{$3 \%$} & \multicolumn{2}{c}{$4 \%$} & \multicolumn{2}{c}{$5 \%$} \\
& 2003 & 2004 & 2003 & 2004 & 2003 & 2004 \\
\hline P. guineense & $5.2^{\mathrm{a}}$ & $5.7^{\mathrm{a}}$ & $5.7^{\mathrm{a}}$ & $6.0^{\mathrm{a}}$ & $6.2^{\mathrm{a}}$ & $6.6^{\mathrm{a}}$ \\
C. annum & $3.0^{\mathrm{b}}$ & $3.5^{\mathrm{c}}$ & $4.5^{\mathrm{b}}$ & $4.8^{\mathrm{b}}$ & $4.9^{\mathrm{c}}$ & $5.3^{\mathrm{c}}$ \\
A. sativum & $3.9^{\mathrm{b}}$ & $4.4^{\mathrm{b}}$ & $4.6^{\mathrm{b}}$ & $4.9^{\mathrm{b}}$ & $5.4^{\mathrm{b}}$ & $5.8^{\mathrm{b}}$ \\
X. aethiopica & $4.8^{\mathrm{ab}}$ & $5.3^{\mathrm{a}}$ & $5.4^{\mathrm{a}}$ & $5.7^{\mathrm{a}}$ & $6.0^{\mathrm{a}}$ & $6.4^{\mathrm{a}}$ \\
Z. officinale & $4.2^{\mathrm{b}}$ & $4.7^{\mathrm{b}}$ & $4.9^{\mathrm{b}}$ & $5.2^{\mathrm{b}}$ & $5.5^{\mathrm{b}}$ & $5.9^{\mathrm{b}}$ \\
Control & $2.6^{\mathrm{c}}$ & $3.1^{\mathrm{c}}$ & $3.0^{\mathrm{c}}$ & $3.3^{\mathrm{c}}$ & $3.6^{\mathrm{d}}$ & $4.0^{\mathrm{d}}$ \\
\hline
\end{tabular}

Means in the same column and followed by different letters are significantly different $(\mathrm{P}<0.05)$ DMRT

Table 2 (a). Mean Population of insects per treatment observed at various intervals after planting (2003 season)

\begin{tabular}{lccccccccc}
\hline & \multicolumn{4}{c}{ Time interval after planting/Treatment levels } \\
\cline { 2 - 10 } Treatment & \multicolumn{3}{c}{4 Weeks } & \multicolumn{4}{c}{8 Weeks } & \multicolumn{5}{c}{12 Weeks } \\
& $3 \%$ & $4 \%$ & $5 \%$ & $3 \%$ & $4 \%$ & $5 \%$ & $3 \%$ & $4 \%$ & $5 \%$ \\
\hline P. guineense & 1.2 & .6 & 0.6 & 1.0 & 0.4 & 0.4 & 0.8 & 0.2 & 0.4 \\
C. annum & 1.2 & 1.0 & 0.8 & 0.8 & 0.8 & 0.6 & 1.0 & 0.6 & 0.6 \\
A. sativum & 1.8 & 1.2 & 1.2 & 1.2 & 1.0 & 0.8 & 0.6 & 0.6 & 0.6 \\
X. aethiopica & 1.6 & 1.0 & 0.4 & 1.4 & 0.6 & 0.4 & 1.0 & 0.2 & 0.2 \\
Z. officinale & 2.0 & 1.6 & 1.2 & 1.8 & 1.2 & 1.0 & 0.2 & 0.6 & 0.2 \\
Control & 2.4 & 2.0 & 1.4 & 2.2 & 1.4 & 1.4 & 2.0 & 1.2 & 1.6 \\
LSD & 0.45 & 0.16 & 0.84 & 0.76 & 0.70 & 0.82 & 0.86 & 1.12 & 0.92 \\
\hline
\end{tabular}

Table 2 (b). Mean Population of insects per treatment observed at various intervals after planting (2004 season)

\begin{tabular}{lccccccccc}
\hline \multirow{2}{*}{ Treatment } & \multicolumn{3}{c}{ Time interval after planting/Treatment levels } \\
\cline { 2 - 10 } & $3 \%$ & $4 \%$ & $5 \%$ & $3 \%$ & $4 \%$ & $5 \%$ & $3 \%$ & $4 \%$ & $5 \%$ \\
\hline P. guineense & 1.1 & 0.7 & 0.5 & 1.0 & 0.2 & 0.2 & 0.6 & 0.2 & 0.4 \\
C. annum & 1.1 & 1.1 & 0.7 & 0.6 & 0.6 & 0.6 & 0.8 & 0.6 & 0.4 \\
A. sativum & 1.7 & 1.3 & 1.0 & 1.0 & 0.8 & 0.4 & 0.6 & 0.6 & 0.6 \\
X. aethiopica & 1.5 & 0.9 & 0.6 & 1.2 & 0.4 & 0.2 & 0.8 & 0.4 & 0.2 \\
Z. officinale & 2.1 & 1.7 & 1.0 & 1.6 & 1.0 & 0.8 & 0.6 & 0.4 & 0.2 \\
Control & 2.6 & 2.2 & 1.8 & 2.8 & 1.6 & 1.8 & 2.4 & 1.8 & 1.8 \\
LSD & 1.12 & 0.82 & 0.45 & 0.82 & 0.90 & 0.16 & 0.70 & 0.84 & 1.02 \\
\hline
\end{tabular}

The weight of seeds recorded after harvesting for the two seasons is recorded in Table 3. Plots treated with $P$. 
guineense gave the highest significant $(\mathrm{P}<0.05)$ weight of $23.14 \mathrm{~g}$ per 100 seeds selected randomly. This was closely followed with plots treated with $C$. anum giving a seed weight of $22.70 \mathrm{~g}$ per 100 seeds while plots treated with $Z$. officinale recorded a seed weight of $18.74 \mathrm{~g}$. The least weight was obtained from the control plots recording a seed weight of $12.80 \mathrm{~g}$ per 100 seeds. The same trend was observed in the second planting season for all the treatments applied. The probable reason for the observation could be the ability of the spices to protect cultivated cowpea from insect pest attack and infestation. Such attacks could lead to flower bud abortion, poor grain filling and pod drop which could all lead to low seed yield and weight (Boeke et al., 2004; Emosairue \& Uguru, 2001).

Table 3. Weight (g) of 100 seeds after harvesting and grain yield for the two seasons

\begin{tabular}{lcccc}
\hline \multirow{2}{*}{ Treatment } & \multicolumn{2}{c}{ Weight $(\mathrm{g})$ of 100 seeds } & \multicolumn{2}{c}{ Grain yield $(\mathrm{Kg} / \mathrm{ha})$} \\
\cline { 2 - 5 } & 2003 & 2004 & 2003 & 2004 \\
\hline P. guineense & 23.14 & 23.64 & 281.21 & 287.29 \\
C. annum & 22.70 & 23.30 & 215.42 & 221.11 \\
A. sativum & 19.51 & 20.01 & 100.62 & 103.19 \\
X. aethiopica & 21.64 & 22.14 & 214.34 & 219.29 \\
Z. officinale & 18.74 & 19.24 & 87.59 & 89.93 \\
Control & 12.80 & 13.30 & 45.11 & 46.87 \\
LSD & 2.58 & 2.61 & 11.33 & 12.89 \\
\hline
\end{tabular}

Generally, the significant reduction in pest population, damage level observed and the increased in pod yield in treated plots is a strong indication of the presence of insecticidal properties in the spices which prevented insect attack and damage to flower buds necessary for pod development and yield. This study therefore has confirmed the growing concern for replacing synthetic chemicals with botanicals. P. guineense is locally available and should be promoted amongst the resource poor farmers over synthetic chemicals as it is eco-friendly and will save foreign exchange as well as reduce the time needed to import chemicals.

\section{Acknowledgement}

The author is grateful to staff of the Insect Museum, Institute of Agricultural Research, Zaria for taxonomic identification of the insects and also to Dr. (Mrs.) Uduak Essiett, a botanist with the University of Uyo for identifying the spices.

\section{References}

Akobundu, O. (1982). Weed control in cowpea (Vigna unguiculata) in the humid tropics. Weed Science Journal, 30, 331-334. http://dx.doi.org/10.1080/09670870410001702206

Boeke, S. J., Barnaud, C., van Loon, J. A., Kossous, D. K., van Huis, A., \& Dicke, M. (2004). Efficacy of plant extracts against the cowpea beetle Callosobruchus maculatus. International Journal of Pest Management, 50(4), 251-258.

CPTM. (1982). Cowpea Production Training Manual. Annual Report and Research Highlight. pp. 7- 81.

Denloye, A. A. B., \& Makanjuola, W. A. (2001). Insecticidal promise of plant terpenoids for the control of insect pests of stored grains in the $21^{\text {st }}$ Century. Journal of Research and Review in Science, 2, 271-288.

Dike, M. C., Emechebe, A. M., Voli, J. P., \& Olufajo, O. O. (1996). Evaluation of Azadirachta indica (neem) products for the control of field insect pests of cowpea at Samaria, Zaria. Ent. Soc. Of Nig. Book of Abstracts $27^{\text {th }}$ Annual Conf. p16.

Emosairue, S. O., \& Ubana, U. B. (1998). Field evaluation of Neem for the control of some cowpea insect pests in South Eastern Nigeria. Global Journal of Pure and Applied Science, 4(3), 233-241.

Emosairue, S. O., \& Uguru, I. (2001). Field trials of aqueous and petroleum ether extracts of Monodora myristica and Jatropha curcas for the control of okra flea beetles (Podagrica spp.). Annals of Agricultural Sciences, 2(2), 40-47.

Epidi, T. T., \& Udo, I. O. (2009). Biological activity of Ethanolic extract fractions of Dracaena arborea against 
infestation of stored grains by two storage insect pests. Pakistan Journal of Biological Sciences, 12(13), 976-980. http://dx.doi.org/10.3923/pjbs.2009.976.980

FAO. (1986). Food and Agricultural Organisation. Annual Report and Research Highlights. pp. 10-16.

Jackai, L. E. N., Inang, E. E., \& Nwobi, P. (1992). The potential for controlling post flowering pests of cowpea, Vigna unguiculata Walp using neem Azadirachta indica A. Juss. Tropical Pest Management, 38, 56-60. http://dx.doi.org/10.1080/09670879209371646

Jackai, L. E. N. (1993). The use of Neem in controlling cowpea pests. IITA Reasearch, 7, 5-11.

Obeng-Ofori, D. (1995). Plant oils as grain protectants against infestation of Cryptolestes pusillus and Rhyzopertha dominica in stored grain. Entomologia Experimentalis et Applicata, 77, 133-139. http://dx.doi.org/10.1111/j.1570-7458.1995.tb01993.x

Obeng-Ofori, D., Reichmuth, C. H., Bekele, J., \& Hassanali, A. (1997). Biological activity of 1,8 cineole, a major component of essential oil of Ocimum kenyense (Ayobangira) against stored product beetles. Journal of Applied Entomology, 121, 237-243. http://dx.doi.org/10.1111/j.1439-0418.1997.tb01399.x

Onwueme, I. C., \& Sinha, T. D. (1991). Field crop production in tropical Africa; Principles and practice. Technical Centre for Agricultural and Rural Co-operative Nigeria. pp. 292-298.

Udo, I. O., Obeng-Ofori, D., \& Owusu, E. O. (2004). Biological effect of methanol extracts of Candlewood Zanthoxylum xanthoxyloides (Lam) against infestation of stored maize and cowpea by three stored products beetles. Global Journal of Pure and Applied Sciences, 10(2), 227-233.

Udo, I. O. (2005). Evaluation of the potential of some local spices as stored grain protectants against maize weevil Sitophilus zeamais Mots (Coleoptera: Curculionidae). J. Appl. Sc. \& Env. Mgt., 9(1), 165-168. http://dx.doi.org/10.4314/gjpas.v10i2.16386

Udo, I. O. (2009). Integrated Pest management (IPM) approach for the control of Sitophilus zeamais Mots and Callosobruchus maculatus (F) on stored grains. Journal of Research in Agriculture, 6(4), 116-120.

Wahua, T. A. T. (1999). Applied Statistics for Scientific Studies. Africa-link Books, Aba. pp. 356. 